\title{
Cambogin exerts anti-proliferative and pro-apoptotic effects on breast adenocarcinoma through the induction of NADPH oxidase 1 and the alteration of mitochondrial morphology and dynamics
}

\author{
Kaikai Shen ${ }^{1, *}$, Fangfang Lu ${ }^{1, *}$, Jianling Xie ${ }^{4,5}$, Minfeng Wu ${ }^{1}$, Bo Cai ${ }^{1}$, Yurong Liu ${ }^{1}$, \\ Hong Zhang ${ }^{1,3}$, Hongsheng Tan ${ }^{1,3}$, Yingyi Pan ${ }^{1}$, Hongxi $X_{\mathbf{u}^{1,2,3}}$ \\ ${ }^{1}$ School of Pharmacy, Shanghai University of Traditional Chinese Medicine, Shanghai 201203, China \\ ${ }^{2}$ Institute of Arthritis Research, Shanghai Academy of Chinese Medical Sciences, Guanghua Integrative Medicine Hospital/ \\ Shanghai University of T.C.M, Shanghai 201203, China \\ ${ }^{3}$ Engineering Research Center of Shanghai Colleges for TCM New Drug Discovery, Shanghai 201203, China \\ ${ }^{4}$ Nutrition \& Metabolism, South Australian Health \& Medical Research Institute, North Terrace, Adelaide SA5000, Australia \\ ${ }^{5}$ Centre for Biological Sciences, Life Sciences Building, University of Southampton, Southampton, SO17 1BJ, UK \\ *These authors have contributed equally to this work \\ Correspondence to: Hongxi Xu, email: xuhongxi88@gmail.com \\ Yingyi Pan, email: pyy16@126.com \\ Keywords: breast cancer, cambogin, reactive oxygen species, NADPH oxidase 1, thioredoxin-1/ASK 1 complex \\ Received: December 02, 2015 \\ Accepted: June 29, 2016 \\ Published: July 13, 2016
}

\section{ABSTRACT}

Cambogin, a bioactive polycyclic polyprenylated acylphoroglucinol (PPAP) derived from the Garcinia genus, possesses proapoptotic effect in medulloblastoma and breast cancer cells. We have previously demonstrated that the proapoptotic effect of cambogin is driven by the production of reactive oxygen species (ROS). Here we have shown that the inhibitory effect of cambogin on cell proliferation is associated with the loss of mitochondrial transmembrane potential $\left(\Delta \Psi_{m}\right)$ and mitochondrial fragmentation. Cambogin also promotes the mutual complex formation of the membrane-bound subunit p22 ${ }^{\text {phox }}$ of NADPH oxidase 1 (NOX1), as well as the phosphorylation of the cytosolic subunit $\mathrm{p} 47^{\text {phox }}$, subsequently enhancing membranebound NOX1 activity, which leads to increases in intracellular and mitochondrial levels of $\mathrm{O}_{2} \cdot-$ and $\mathrm{H}_{2} \mathrm{O}_{2}$. Pharmacological inhibition of NOX1 using apocynin (pan-NOX inhibitor), ML171 (NOX1 inhibitor) or siRNA against NOX1 prevents the increases in $\mathrm{O}_{2} \cdot-$ and $\mathrm{H}_{2} \mathrm{O}_{2}$ levels and the anti-proliferative effect of cambogin. Antioxidants, including SOD (superoxide dismutase), CAT (catalase) and EUK-8, are also able to restore cell viability in the presence of cambogin. Besides, cambogin increases the dissociation of thioredoxin-1 (TrX1) from ASK1, switching the inactive form of ASK1 to the active kinase, subsequently leads to the phosphorylation of JNK/SAPK, which is abolished upon ML171 treatment. The proapoptotic effect of cambogin in breast cancer cells is also aggravated upon knocking down Trx1 in MCF-7 cells. Taken in conjunction, these data indicate that the anti-proliferative and pro-apoptotic effect of cambogin is mediated via inducing NOX1-dependent ROS production and the dissociation of ASK1 and Trx1.

\section{INTRODUCTION}

Breast cancer is the most common malignancy in women worldwide despite early diagnosis and aggressive therapeutic methods [1]. In light of the recognition that alcohol consumption, obesity, lack of physical exercise, hormone replacement therapy during menopause and ionizing radiation are the main risk factors for breast cancer, it is envisaged that the incidence of breast cancer will remain high and the existing treatments unfortunately have only limited efficacy in slowing down clinical decline [2]. 
Reactive oxygen species (ROS), such as hydrogen peroxide $\left(\mathrm{H}_{2} \mathrm{O}_{2}\right)$ and the highly reactive hydroxyl radical, are recognized as a second messenger in a variety of cell receptor signal transduction pathways [3]. ROS exerts a pivotal role in a number of cellular processes associated with tumor progression, including survival, proliferation, invasion, angiogenesis and metastasis [4-6]. Most of the currently available anti-cancerous chemotherapeutic, photodynamic and radiotherapeutic agents are selectively toxic to tumor cells by augmenting oxidative stress, resulting in sustained cell-cycle inhibition, cell death induction, and senescence, in the present, this likely represents one of the best opportunities for cancer therapeutics [7-9]. Several intracellular sources can contribute to the production of ROS, such as cyclooxygenase, cytochrome P450, lipoxygenases, mitochondrial electron transport, xanthine oxidase and NADPH oxidase (NOX) [10, 11]. In non-phagocytic cells, the NOX enzymes are the key component of the so-called "redox signaling system" that regulate many cellular responses by modulating intracellular ROS content [12]. NOX is a superoxide-producing enzyme system consisting of membrane-bound subunits, including gp9 $1^{\text {phox }}$ homologues (NOX1-5, Duox1 and Duox2) and p2 $2^{\text {phox }}$; cytosolic subunits ( $47^{\text {phox }}, \mathrm{p} 67^{\text {phox }}$, and p40 ${ }^{\text {phox }}$ ), and the small GPTase Rac [13-15]. Upon activation, the transmembrane subunit $\mathrm{p} 22^{\text {phox }}$ first forms a mutually stabilized complex with gp9 $91^{\text {phox }}$ homologues, followed by the phosphorylation of the cytosolic subunit $\mathrm{p} 47^{\mathrm{phox}}$ and the entire cytosolic complex interacts with the small GTPase Rac and translocate to the plasma membrane, where all components assemble to form the active complex $[13,14$, $16,17]$. This system is considered to be the predominant source of ROS accumulation and oxidative stress in response to oncogenic signals as well as DNA-damaging agents in cancer cells.

On the other hand, Garcinia species are tropical evergreen trees and shrubs that are widely distributed in Southeastern Asia and used in folk medicine to promote detoxification in the treatment of inflammation and wounds [18]. Polycyclic polyprenylated acylphloroglucinols (PPAPs), one of the main bioactive components, are known to possess anticancer activities, including the induction of apoptosis, the inhibition of proliferation, and the prevention of cancer metastasis and tumor angiogenesis [19-21]. One of the mechanisms by which PPAPs exert anti-tumor effect is via elevating the levels of ROS [21, 22]. Cambogin is a bioactive PPAP isolated from the branches of Garcinia esculenta [23]. Previously we have shown that cambogin induces breast adenocarcinoma cell apoptosis via ROS-mediated increases in Bax/Bcl-2 ratio and the nuclear import of apoptosis inducing factor (AIF), in parallel with the stimulation of ASK1-MKK4/ MKK7-JNK/SAPK signaling cascade [21]. However, the underlying mechanism of how cambogin promotes ROS formation remains elusive. In the present study, we identified the NOX system as a crucial regulator of ROSdependent cell apoptosis in response to cambogin in breast adenocarcinoma.

\section{RESULTS}

\section{The reduction in breast cancer cell viability in response to cambogin is associated with alterations in mitochondria morphology and dynamics}

We have reported previously [21] that cambogin (chemical structure shown in Figure 1A) strongly inhibits cell proliferation in several breast cancer cell lines, including MCF-7 (ER ${ }^{+} \mathrm{PR}^{+} \mathrm{HER} 2^{-}$), SK-BR-3 (ER-PR HER $2^{+}$) and MDA-MB-468 (ER-PR-HER2', also known as TNBC (triple negative breast cancer)). As shown in Figure $1 \mathrm{~B}$, cambogin $(0-10 \mu \mathrm{M})$ treatment led to a reduction in MCF-7 cell viability in a dose-dependent manner, which can be achieved with a concentration as low as $1.25 \mu \mathrm{M}$, whereas at $10 \mu \mathrm{M}$ it produced the maximal inhibition. The $\mathrm{IC}_{50}$ value of cambogin was $4.91 \mu \mathrm{M}$ for MCF-7 cells. Therefore, we chose to use $1.25 \mu \mathrm{M}, 2.5 \mu \mathrm{M}, 5 \mu \mathrm{M}$ and 10 $\mu \mathrm{M}$ final concentrations of cambogin treatment, as a weak, low, medium and strong, respectively, inducer of apoptosis throughout the present study.

Depolarization of the mitochondrial transmembrane potential $\left(\Delta \Psi_{\mathrm{m}}\right)$ has been suggested to be central to the intrinsic apoptotic pathway [24], it is characterized by the permeabilization of the mitochondrial outer membrane, which occurs in response to various stress stimuli and is regulated by the release of a number of apoptogenic factors including members of the Bcl-2 family [25]. Since cambogin has been demonstrated to cause an increase in the pro-apoptotic Bax/anti-apoptotic Bcl-2 ratio in MCF-7 cells [21], we asked whether cambogin affected $\Delta \Psi_{\mathrm{m}}$. We measured $\Delta \Psi_{\mathrm{m}}$ by using the fluorescent dye JC-1. A reduction in $\Delta \Psi_{\mathrm{m}}^{\mathrm{m}}$ is associated with a decrease in the red/green fluorescent ratio. Breast cancer cells exposed to concentrations of cambogin ranging 1.25 to $10 \mu \mathrm{M}$ exhibited a dissipation of $\Delta \Psi_{\mathrm{m}}$ in a concentrationdependent manner, as demonstrated by a decrease in red/ green ratio in MCF-7 (Figure 1C and 1D), MDA-MB-468 (Supplementary Figure 1A and 1B) and SK-BR-3 cells (Supplementary Figure 1C and 1D). Since $\Delta \Psi_{\mathrm{m}}$ dissipation is often associated with the permeabilization of the outer mitochondrial membrane and oxidative stress results in mitochondrial network abnormalities, we investigated whether cambogin affected mitochondrial network in breast cancer cells. In control cells, mitochondria mainly exhibited a tubular length of $15.4 \pm 4.6 \mu \mathrm{m}$, a hallmark of well-balanced fission and fusion (Figure 1E and 1F). Cambogin treated cells showed multiple mitochondrial network abnormalities in a dose-dependent manner in MCF-7 cells. For instance, $24 \mathrm{~h}$ of treatment with low concentrations of cambogin $(1.25 \mu \mathrm{M})$ resulted in a modest 
A<smiles>[AlH2]</smiles>

B

$\mathbf{E}$
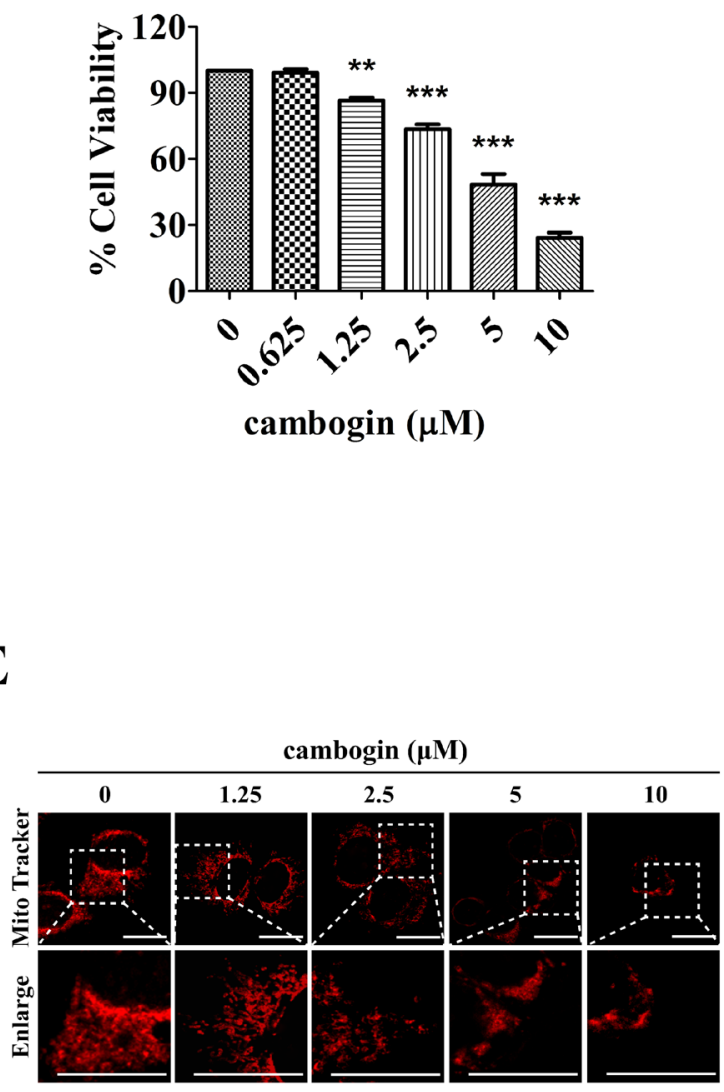

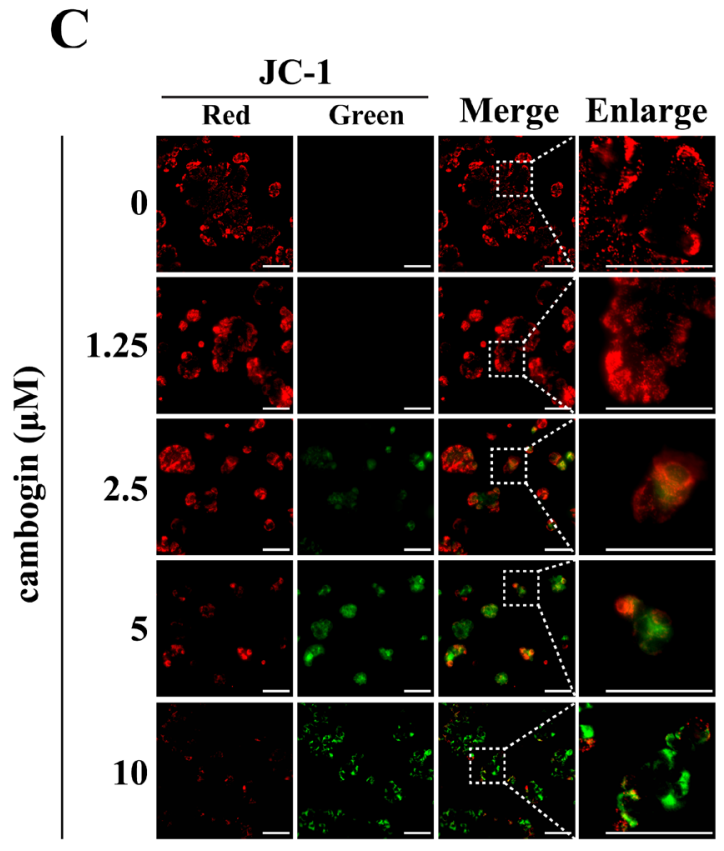

D

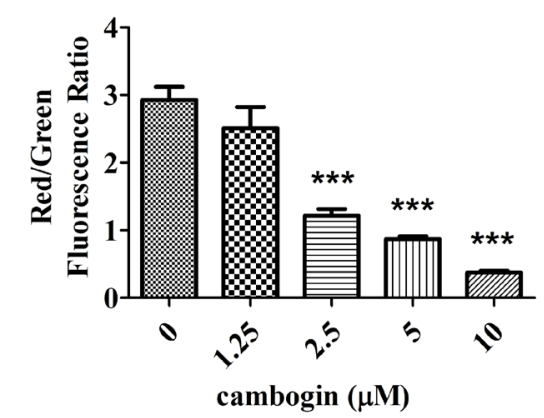

$\mathbf{F}$

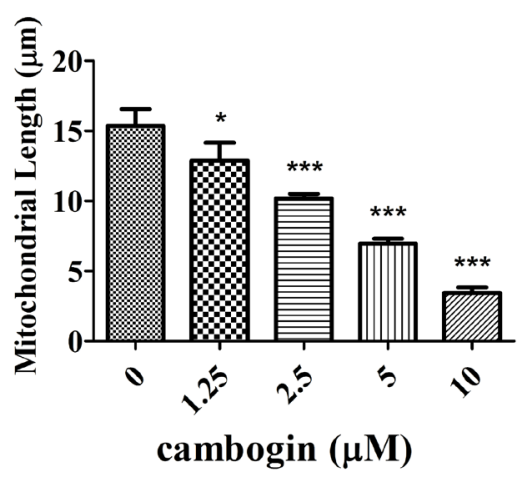

Figure 1: Cambogin inhibits cell proliferation and modulates mitochondrial network in MCF-7 cells. A. Chemical structure of cambogin. B. MCF-7 cells were treated with cambogin $(0-10 \mu \mathrm{M})$ for $24 \mathrm{~h}$. Cell viability was measured by MTT assay. C, D. MCF-7 cells were exposed to cambogin $(0-10 \mu \mathrm{M})$ for $4 \mathrm{~h}$. The percentage of cells with a reduction in $\Delta \Psi \mathrm{m}$ was measured using the fluorescent dye JC-1 $(10 \mu \mathrm{M})$. After incubation, stained cells were observed under an inverted fluorescent microscope $(\mathrm{C})$ and were measured by microplate fluorescence reader (D). JC-1 dye changes color as the membrane potential increases. At higher membrane potentials, JC-1 forms aggregates, which changes the fluorescence emission color from green to red. Scale bar $=100 \mu \mathrm{m}$. E. MCF-7 cells were treated with cambogin $(0-10 \mu \mathrm{M})$ for $24 \mathrm{~h}$. After treatment, the cells were washed, stained with MitoTracker Red for $1 \mathrm{~h}$, washed again, and analyzed for mitochondrial network under confocal microscopy $(\times 1000)$. Scale bar $=20 \mu \mathrm{m}$. F. Statistical analyses of the average mitochondrial length for experiment E. Data are shown as means $\pm \mathrm{SEM} ;{ }^{*} P<0.05,{ }^{* *} P<0.01,{ }^{* * *} P<0.001$ compared with control. $n=3$. 
mitochondrial truncation, as evidenced by a shortened mitochondria average length $(12.8 \pm 4.0 \mu \mathrm{m})$ (Figure $1 \mathrm{E}$ and $1 \mathrm{~F})$. Substantial mitochondrial fragmentation occurred with $10 \mu \mathrm{M}$ cambogin treatment, resulting in extremely short mitochondria (average length $3.0 \pm 1.5$ $\mu \mathrm{m})$ (Figure 1E and $1 \mathrm{~F}$ ). The majority of the mitochondria became punctate and clustered. Likewise, cambogin induced the alteration of mitochondrial morphology and dynamics in MDA-MB-468 (Supplementary Figure 2A and $2 \mathrm{~B}$ ) and SK-BR-3 cells (Supplementary Figure 2C and 2D). These results suggest that cambogin treatment induces mitochondrial fragmentation and clustering, and subsequently leads to a reduction in $\Delta \Psi_{\mathrm{m}}$, which are associated with apoptosis in MCF-7 cells.

\section{Cambogin increases intracellular and mitochondrial levels of $\mathrm{H}_{2} \mathrm{O}_{2}$ and hence ROS production}

The generation of ROS plays a critical role in the proapoptotic activities of various anticancer agents [2628]. In MCF-7 cells, cambogin caused a concentrationdependent increase in ROS production, with the minimal effective concentration of $5 \mu \mathrm{M}$ (Figure $2 \mathrm{~A}$ and $2 \mathrm{~B}$ ). A dose-dependent increase in intracellular $\mathrm{O}_{2}^{--}$levels was detected in MCF-7 cells following incubation with cambogin (Figure 2C and 2D). Cells were treated with increasing doses of cambogin, and were then stained with the mitochondria-targeting dye MitoSOX ${ }^{\mathrm{TM}}$, which serves as a fluoroprobe for selective detection of superoxide in the mitochondria. Cambogin treatment substantially increased mitochondrial $\mathrm{O}_{2}-{ }^{-}$levels in a dose-dependent manner in MCF-7 cells (Figure 2E and 2F), and this is accompanied by an increase in the production of $\mathrm{H}_{2} \mathrm{O}_{2}$ but not nitric oxide (NO) (Supplementary Figure 2E and 2F). It can be inferred from the fact that the enhancement of ROS generation is attributed to the production of mitochondrial $\mathrm{O}_{2}{ }^{-}$as well as intracellular $\mathrm{O}_{2}{ }^{-}$. Antioxidants, including $\mathrm{SOD}\left(\mathrm{O}_{2}-{ }^{-}\right.$scavenger $)$, CAT $\left(\mathrm{H}_{2} \mathrm{O}_{2}\right.$ scavenger $)$ and EUK8 (synthetic catalytic superoxide and hydrogen peroxide scavenger), significantly prevented the inhibitory effect of cambogin on cell proliferation at $24 \mathrm{~h}$ by MTT assay (Figure 2G) and by SYBR Green assay (Supplementary Figure 3A).

\section{The activation of NOX is crucial for cambogin- mediated ROS production}

The superoxide anion radical generating enzymes NOX are dedicated to the specific and deliberate production of free radicals [13]. Cambogin evoked a substantial increase in NOX activity in the membrane fractions of treated cells in comparison with the untreated ones in MCF-7 (Figure 3A), MDA-MB-468 (Supplementary Figure 4A) and SK-BR-3 (Supplementary Figure 4B). In contrast, NOX activity was merely detectable in both control and cambogin-treated cells in the cytosolic fractions, implying that cambogin enhances the activity of membrane-bound NOX in breast cancer cells (Figure 3A and Supplementary Figure 4). Besides, pan-NOX inhibitor apocynin prevented cambogininduced production of $\mathrm{O}_{2}^{-}$and $\mathrm{H}_{2} \mathrm{O}_{2}$ (Figure 3B-3D) and the pro-apoptotic effect of cambogin was also abolished by apocynin (Figure 3E and Supplementary Figure 3B). These results strongly suggest that the NOX system is crucial for the generation of ROS in response to cambogin.

\section{Cambogin enhances the interaction between NOX1 and p22 ${ }^{\text {phox }}$}

The activation of NOX initiates when the membrane-bound subunit $\mathrm{p} 22^{\text {phox }}$ forms a mutually stabilizing complex with the NOX isoforms, followed by the phosphorylation of the cytosolic subunit $\mathrm{p} 47^{\text {phox }}$, and subsequently the entire cytosolic complex associates with the small GTPase Rac which translocates it to the plasma membrane, where all components assemble to form the active complex [16]. In MCF-7 cells, exposure to cambogin stimulated the tyrosine phosphorylation of $\mathrm{p} 47^{\text {phox }}$ within 30 min of incubation, and this phosphorylation event persisted for up to at least $4 \mathrm{~h}$ (Figure 4A). Cambogin treatment also enhanced the interaction between NOX1 and p22 $2^{\text {phox }}$ (Figure 4B). We used Pearson's correlation coefficient (PCC) to quantitatively determine the rates of co-localization between NOX1 and $\mathrm{p} 22^{\text {phox }}$ (PCC value close to zero reflects poor co-colocalization). In consistent with results from the confocal microscopy, PCC values of cambogin-treated cells were significantly higher than that of the untreated ones (Figure 4C). Previously, we have demonstrated that cambogin is able to suppress breast adenocarcinoma tumor growth without any apparent toxicity in vivo, with a decrease of $73 \%$ of tumor size at the dose of $10 \mathrm{mg} / \mathrm{kg}$ [21]. We also isolated the tumor tissue (MCF-7 xenograft) from animals treated with cambogin $(10 \mathrm{mg} / \mathrm{kg})$ for 35 days, consistent with the in vitro data (Figure 4B and 4C), cambogin indeed enhanced the interaction of NOX1 and $\mathrm{p} 22^{\text {phox }}$ in vivo (Figure 4D and $4 \mathrm{E}$ ). Likewise, cambogin induced an increase in the binding of NOX1 to p22 $2^{\text {phox }}$ after $2 \mathrm{~h}$ of cambogin treatment in MCF-7 cells (Figure 4F). We observed an increase in the expression of NOX1 in the membrane fraction as well as total NOX1 when cells were treated with cambogin (Figure $4 \mathrm{G}$ and $4 \mathrm{H}$ ). However, there was little change in the expression of cytosolic NOX1 (Figure $4 \mathrm{H}$ and $4 \mathrm{I}$ ), suggesting that cambogin treatment alters the assembling and localization of NOX1.

To determine the role of NOX1 in cambogininduced cell apoptotic responses, we used a specific NOX1 inhibitor ML171 [29] as well as NOX1 siRNAs to either inhibit NOX1 activation or knock down NOX1, respectively. ML171 prevented the increases in $\mathrm{O}_{2}$. and $\mathrm{H}_{2} \mathrm{O}_{2}$ production (Figure $5 \mathrm{~A}-5 \mathrm{C}$ ), cell proliferation 
A

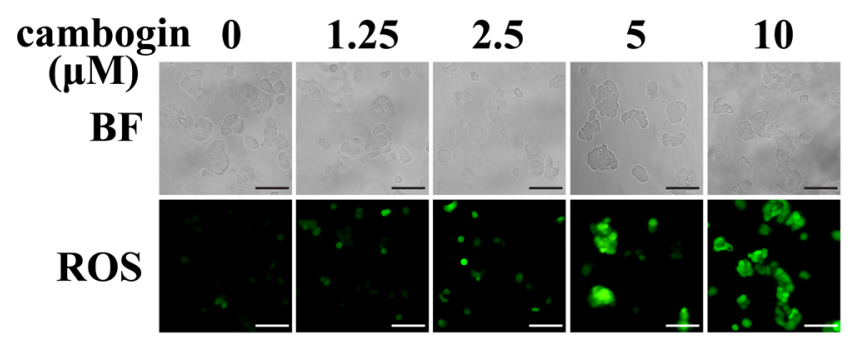

C

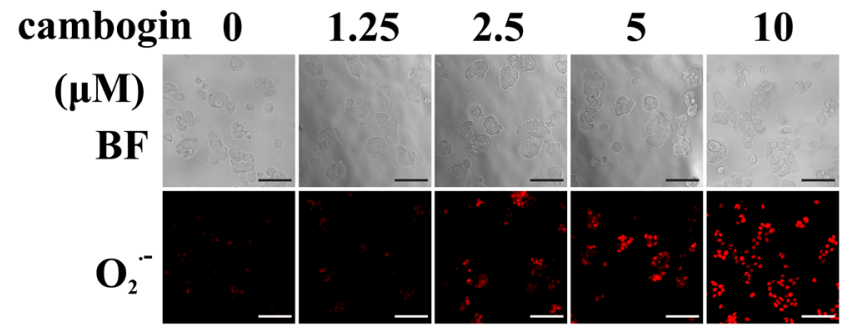

$\mathbf{E}$

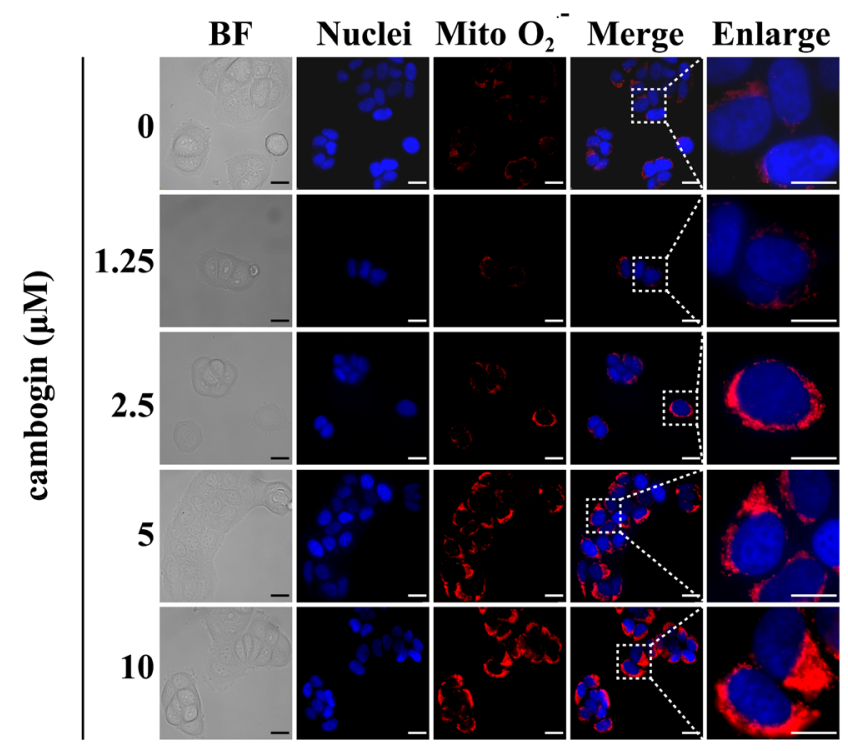

B

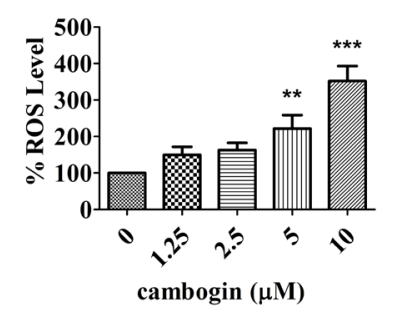

D

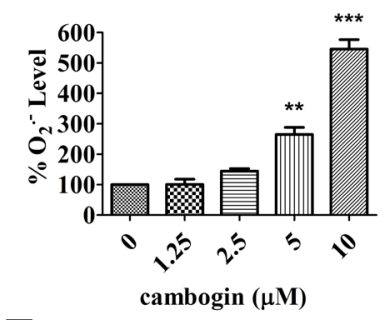

$\mathbf{F}$

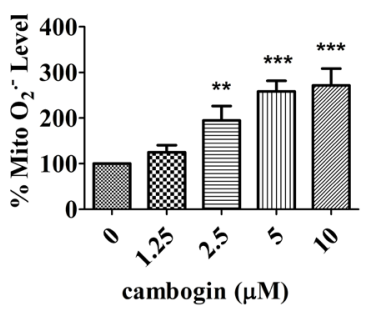

G

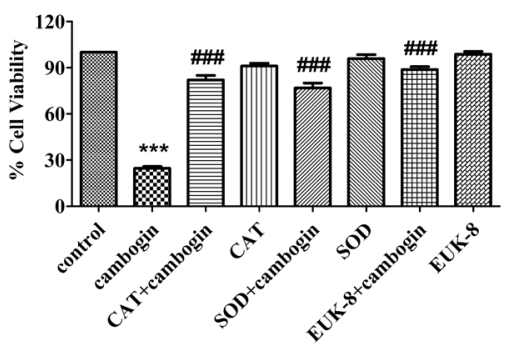

Figure 2: Cambogin induces the generation of ROS in MCF-7 cells. A, B. MCF-7 cells were treated with cambogin (0-10 $\mu \mathrm{M})$ for $2 \mathrm{~h}$. The production of $\mathrm{H}_{2} \mathrm{O}_{2}$ was measured using the fluorescent dye DCFH-DA $(20 \mu \mathrm{M})$. After incubation, stained cells were observed under an inverted fluorescent microscope (A) and the fluorescence intensity units (FIU) were measured at $488 \mathrm{~nm}$ (excitation wavelength) and $525 \mathrm{~nm}$ (emission wavelength) (B). Scale bar=100 $\mu \mathrm{m}$. C, D. MCF-7 cells were treated with cambogin $(0-10 \mu \mathrm{M})$ for $2 \mathrm{~h}$. The production of $\mathrm{O}_{2}-$ was measured using the fluorescent dye DHE $(50 \mu \mathrm{M})$. After incubation, stained cells were observed under an inverted fluorescent microscope (C) and FIU was measured at $530 \mathrm{~nm}$ (excitation wavelength) and $610 \mathrm{~nm}$ (emission wavelength) (D). Scale bar $=100 \mu \mathrm{m}$. E, F. MCF-7 cells were treated with cambogin $(0-10 \mu \mathrm{M})$ for $2 \mathrm{~h}$. The production of $\mathrm{O}_{2}-$ was measured using the fluorescent dye MitoSOX ${ }^{\mathrm{TM}}(5 \mu \mathrm{M})$ and Hoechst $33342(10 \mu \mathrm{g} / \mathrm{ml})$. After incubation, stained cells were observed under an inverted fluorescent microscope (E) and FIU was measured at $510 \mathrm{~nm}$ (excitation wavelength) and $580 \mathrm{~nm}$ (emission wavelength) (F). Scale bar=20 $\mu \mathrm{m}$. G. MCF-7 cells were treated with cambogin for $24 \mathrm{~h}$ after pretreatment with CAT $(1000 \mathrm{U} / \mathrm{ml})$, SOD $(100 \mathrm{U} / \mathrm{ml})$, and EUK-8 $(50$ $\mu \mathrm{M})$ for $2 \mathrm{~h}$. Cell viability was measured by MTT assay. Data are shown as means $\pm \mathrm{SEM} ;{ }^{* *} P<0.01,{ }^{* * *} P<0.001$ compared with control; ${ }^{\#} P<0.001$ compared with cambogin. $n=3$. 
inhibition (Figure 5D and Supplementary Figure 3C) and mitochondrial network abnormalities (Figure 5E and 5F) induced by cambogin. On the other hand, NOX1 siRNAs effectively reduced endogenous NOX1 expression (Figure 5G). Cambogin-induced increases in $\mathrm{O}_{2}^{--}$and $\mathrm{H}_{2} \mathrm{O}_{2}$ formation (Figure $5 \mathrm{H}-5 \mathrm{~J}$ ), as well as pro-apoptotic response (Figure 5K and Supplementary Figure 3D) were substantially attenuated by NOX1 siRNAs. These results suggest that NOX1 is responsible for cambogin-mediated ROS production and mitochondrial network abnormalities.

\section{Cambogin causes the dissociation of thioredoxin-1 (Trx1) from ASK1}

We have previously shown that the activation of ASK1/JNK signaling cascade plays an essential role in the anti-proliferative and pro-apoptotic effects of cambogin on breast cancer cells [21]. We applied 2D-gel map analysis combined with tandem mass spectrometry to identify targets that are affected by cambogin treatment in human breast cancer cells. We have identified changes in 53 proteins that are highly related to ROS, and further analysis (by using IPA) has revealed that changes in 12 proteins are highly related to Trx1. It has also been reported that ROS induces apoptosis through the oxidation of ASK1 upstream inhibitor Trx1, and hence releasing ASK1 from its inhibitory binding [30]. In MCF-7 cells, cambogin treatment induced a significant increase in the phosphorylation of ASK1 at Thr845 and JNK/SAPK at Thr183 and Tyr185, concomitant with a decrease in Trx1 expression in a dose-dependent manner (Figure 6A). We investigated the effects of cambogin on the binding of Trx1 to ASK1 as an indicator of the functional redox state of Trx1. As shown in Figure 6B, ASK1 was associated with Trx1 in untreated cells; in contrast, cambogin induced a reduction in the binding of ASK 1 to Trx 1 after $24 \mathrm{~h}$ of treatment. Moreover, the pro-apoptotic effect of cambogin in breast cancer cells was further enhanced in siRNAmediated Trx 1 knocked down MCF-7 cells (Figure 6C and $6 \mathrm{D}$ and Supplementary Figure $3 \mathrm{E}$ ). The proapoptotic effect of cambogin in breast cancer cells was attenuated upon exogenously expressing Trx1 in MCF-7 cells
A

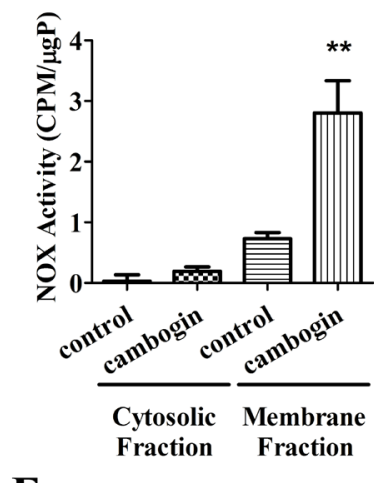

$\mathbf{E}$

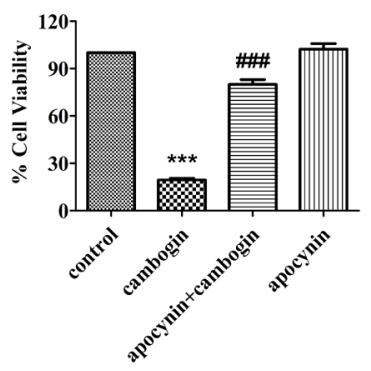

C

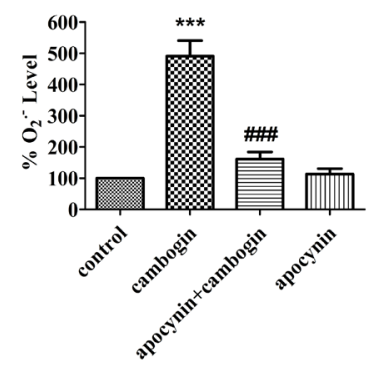

D

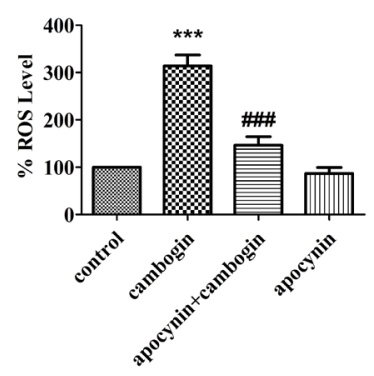

Figure 3: The activation of NOX in response to cambogin is dependent on the generation of ROS. A. MCF-7 cells were incubated in the absence or presence of cambogin $(10 \mu \mathrm{M})$ for $2 \mathrm{~h}$. NOX activity was measured and the enzyme activity is expressed as relative light units (RLU). B. MCF-7 cells were incubated in the absence or presence of cambogin $(10 \mu \mathrm{M})$ for $2 \mathrm{~h}$ after pretreatment with apocynin $(500 \mu \mathrm{M})$ for $2 \mathrm{~h}$. The production of $\mathrm{O}_{2}^{--}$and $\mathrm{H}_{2} \mathrm{O}_{2}$ was measured by DHE (for $\mathrm{O}_{2}^{-{ }^{-}}$) and DCFH-DA (for $\mathrm{H}_{2} \mathrm{O}_{2}$ ) staining. After incubation, stained cells were observed under an inverted fluorescent microscope. Scale bar $=100 \mu \mathrm{m}$. C. The FIU of $\mathrm{O}_{2}^{--}$was measured at $530 \mathrm{~nm}$ (excitation wavelength) and $610 \mathrm{~nm}$ (emission wavelength). D. The FIU of $\mathrm{H}_{2} \mathrm{O}_{2}$ was measured at $488 \mathrm{~nm}$ (excitation wavelength) and $525 \mathrm{~nm}$ (emission wavelength). E. MCF-7 cells were treated with cambogin for $24 \mathrm{~h}$ after pretreatment with apocynin $(500 \mu \mathrm{M})$ for 2 h. Cell viability was measured by MTT assay. Data are shown as means \pm SEM; ${ }^{* *} P<0.01,{ }^{* * *} P<0.001$ compared with control; ${ }^{\# \#} P<0.001$ compared with cambogin. $n=3$. 
(Figure 6E and 6F and Supplementary Figure 3F). The phosphorylation of JNK/SAPK in response to cambogin was effectively abolished by the treatment with ML171 (Figure 6G and $6 \mathrm{H}$ ) or the knocking down NOX1 using siRNA (Figure 6I and 6J). Collectively, these results indicate that cambogin induces ROS production, which leads to the dissociation of Trx 1 from ASK1, switching the inactive form of ASK1 to the active kinase, and subsequently activates JNK/SAPK, and ultimately causes cancer cell death.

\section{DISCUSSION}

It has been well established that ROS are in principal cytotoxic and mutagenic to the cells, and high levels of ROS lead to cell death or senescence [31]. Tumor cells
A

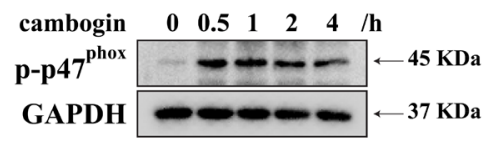

D

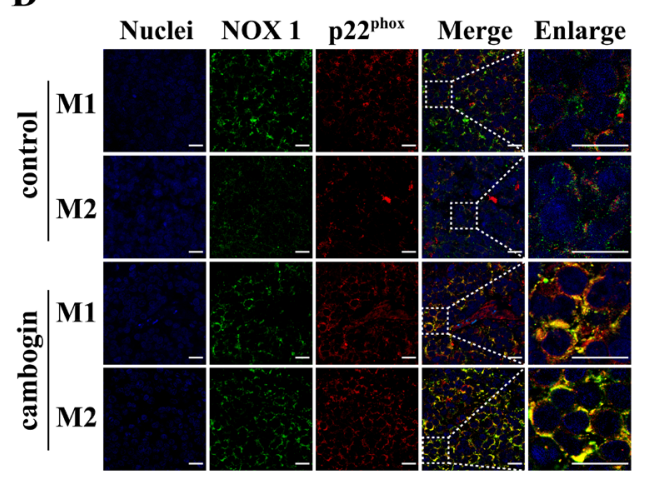

G

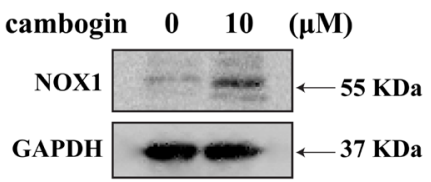

H

B

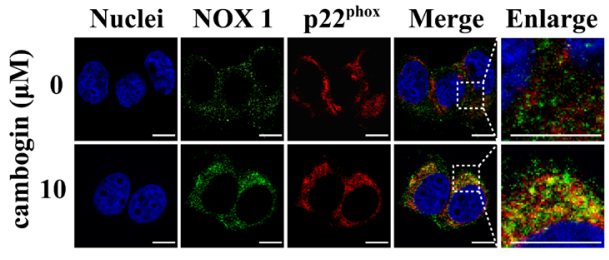

E
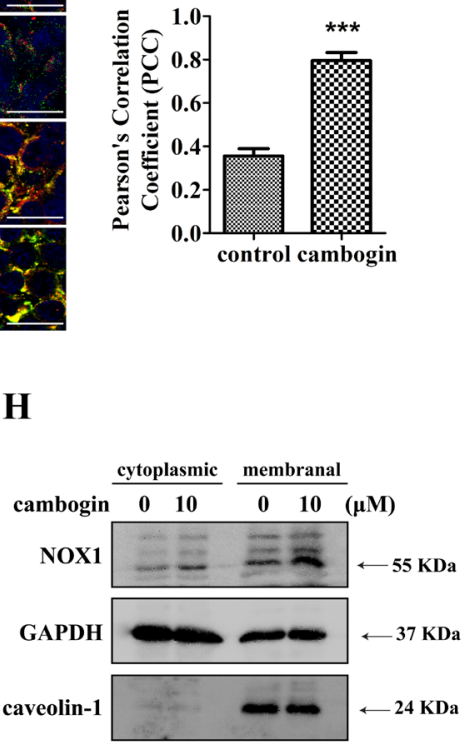

C

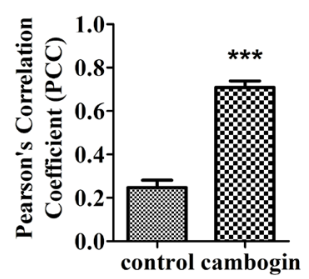

F

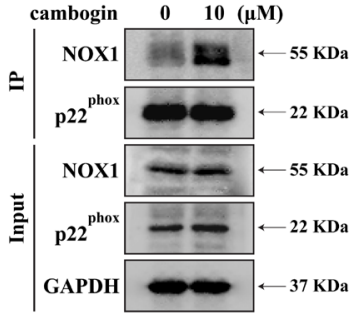

I

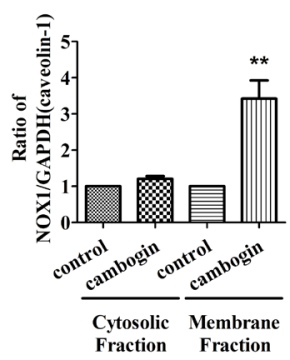

Figure 4: Cambogin enhances the co-localization of NOX1 and p22 ${ }^{\text {phox }}$. A. MCF-7 cells were treated with cambogin $(10 \mu \mathrm{M})$ for the indicated time periods ( $0-4 \mathrm{~h})$ and the expression of p-p47phox and GAPDH were analyzed by SDS-PAGE/Western blotting. B, C. Immunofluorescent staining for NOX1 (green) and p22 ${ }^{\text {phox }}$ (red) in the MCF-7 cells after treatment with cambogin (10 $\left.\mu \mathrm{M}\right)$ for $2 \mathrm{~h}$. The co-localization of NOX1 and p22 phox was observed under confocal microscopy $(\times 630)(\mathrm{B})$ and PCC was applied to statistically quantify the co-localization (C). Scale bar $=10 \mu \mathrm{m}$. D, E. Immunofluorescent staining for NOX1 (green) and p22 ${ }^{\text {phox }}$ (red) in the tumor section after treatment with cambogin $(10 \mathrm{mg} / \mathrm{kg})$ for 35 days. The co-localization of NOX1 and p22 phox was observed with confocal microscopy $(\times 630)$ (D) and PCC was applied as statistic quantification for colocalization (E). Scale bar $=20 \mu \mathrm{m}$. F. MCF-7 cells were incubated in the absence or presence of cambogin $(10 \mu \mathrm{M})$. p22 $2^{\text {phox }}$ was immunoprecipitated from cell lysates using anti-p22 ${ }^{\text {phox }}$ antibody. The immunoprecipitates were then run on a SDS-PAGE gel and probed for anti-NOX1 and anti-p22 ${ }^{\text {phox }}$. G. MCF-7 cells were treated with cambogin for $2 \mathrm{~h}$. The expression of NOX1 and GAPDH was determined by SDS-PAGE/Western blotting. H. MCF-7 cells were treated with cambogin (10 $\mu \mathrm{M})$ for $2 \mathrm{~h}$. The expression of NOX1 in the cytoplasmic and membranal fractions was determined by SDS-PAGE/Western blotting. I. Data are expressed as ratios to GAPDH (cytoplasmic fractions) or caveolin-1 (membranal fractions). Data are shown as means \pm SEM; ${ }^{* *} P<0.01$, ${ }^{* * *} P<0.001$ compared with control. $n=3$. 
A

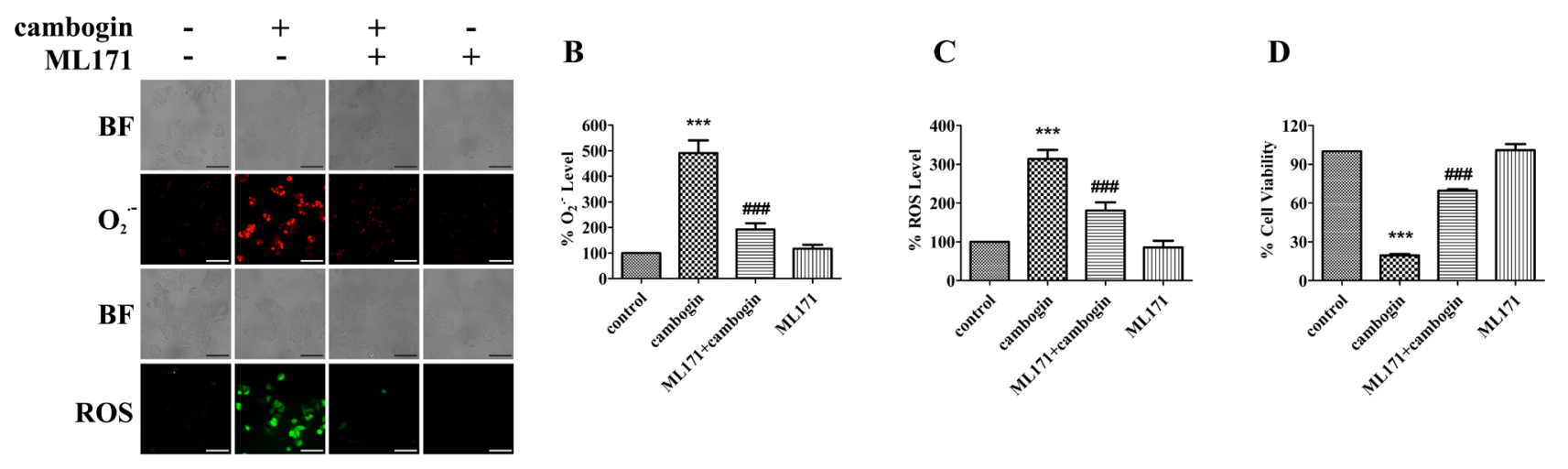

$\mathbf{E}$

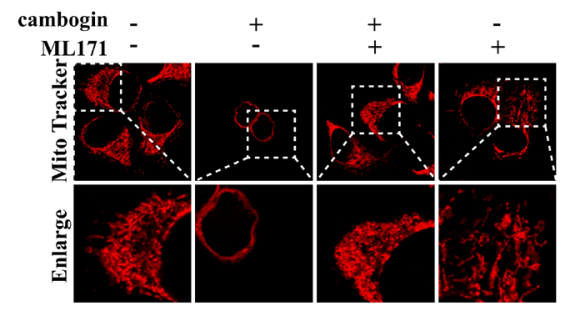

$\mathbf{F}$

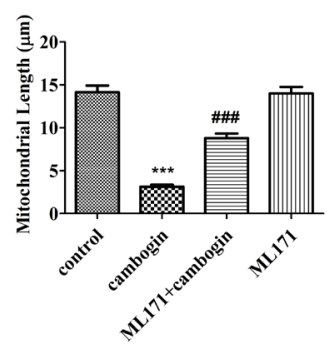

$\mathbf{G}$

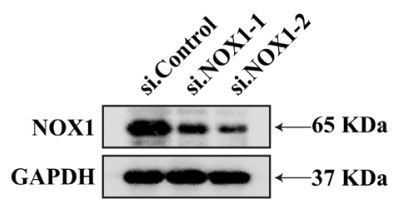

H

I
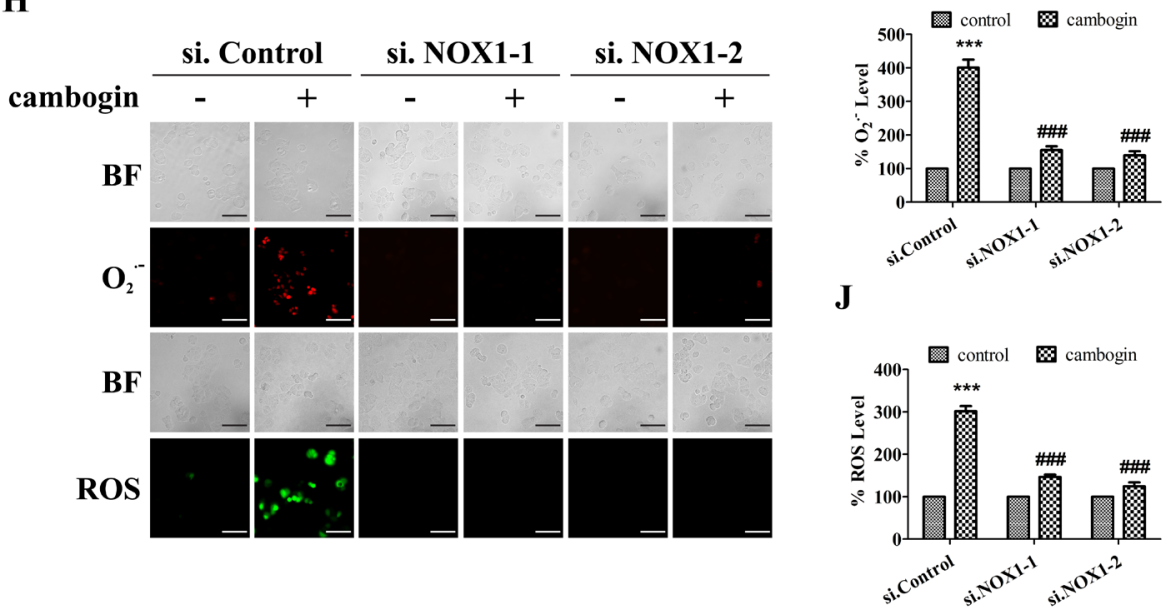

$\mathbf{K}$

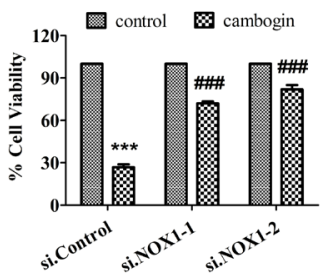

Figure 5: NOX1 is required for cambogin-stimulated generation of ROS. A. MCF-7 cells were incubated in the absence or presence of cambogin $(10 \mu \mathrm{M})$ for $2 \mathrm{~h}$ after pretreatment with ML171 $(20 \mu \mathrm{M})$ for $2 \mathrm{~h}$. The production of $\mathrm{O}_{2}{ }^{-}$and $\mathrm{H}_{2} \mathrm{O}_{2}$ were measured by DHE (for $\mathrm{O}_{2}^{-}$) and DCFH-DA (for $\mathrm{H}_{2} \mathrm{O}_{2}$ ) staining. After incubation, stained cells were observed under an inverted fluorescent microscope. Scale bar $=100 \mu \mathrm{m}$. B. The FIU of $\mathrm{O}_{2}^{--}$was measured at $530 \mathrm{~nm}$ (excitation wavelength) and $610 \mathrm{~nm}$ (emission wavelength). C. The FIU of $\mathrm{H}_{2} \mathrm{O}_{2}$ was measured at $488 \mathrm{~nm}$ (excitation wavelength) and $525 \mathrm{~nm}$ (emission wavelength). D. MCF-7 cells were treated with cambogin for $24 \mathrm{~h}$ after pretreatment with ML171 $(20 \mu \mathrm{M})$ for $2 \mathrm{~h}$. Cell viability was measured by MTT assay. E. MCF-7 cells were treated with cambogin for $24 \mathrm{~h}$ after pre-treatment with ML171 $(20 \mu \mathrm{M})$ for $2 \mathrm{~h}$. The cells were then washed with HBSS by three times, stained with MitoTracker Red for $1 \mathrm{~h}$, washed, and analyzed for mitochondrial network under confocal microscopy $(\times 1000)$. Scale bar $=20 \mu \mathrm{m}$. F. Statistical analyses of the average mitochondrial length for E. G. MCF-7 cells were transiently transfected with two independent NOX1 siRNAs (si.NOX1-1 and si.NOX1-2) or control scrambled siRNA (si.Control) for $48 \mathrm{~h}$, NOX1 protein expression levels were determined by SDS-PAGE/Western blotting. GAPDH was served as a loading control. $\mathbf{H}$. The production of $\mathrm{O}_{2}^{--}$and $\mathrm{H}_{2} \mathrm{O}_{2}$ was measured by DHE (for $\mathrm{O}_{2}^{-}$) and DCFH-DA (for $\mathrm{H}_{2} \mathrm{O}_{2}$ ) staining in cambogin-inhibited, NOX1-knocked down (as in G) MCF-7 cells. Scale bar=100 $\mu$ m. I. The FIU of $\mathrm{O}_{2}{ }^{--}$was measured at $530 \mathrm{~nm}$ (excitation wavelength) and $610 \mathrm{~nm}$ (emission wavelength). J. The FIU of $\mathrm{H}_{2} \mathrm{O}_{2}$ was measured at $488 \mathrm{~nm}$ (excitation wavelength) and $525 \mathrm{~nm}$ (emission wavelength). K. Cell viability was determined in cambogin-inhibited, NOX1-knocked down MCF-7 cells for 24 h. Data are shown as means $\pm \mathrm{SEM} ;{ }^{* * *} P<0.001$ compared with control; ${ }^{\# \#} P<0.001$ compared with cambogin-treated cells. $n=3$. 
A

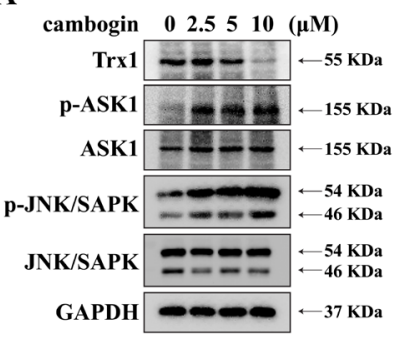

$\mathbf{B}$

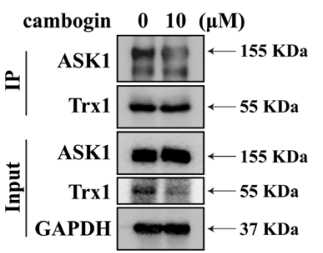

C

D

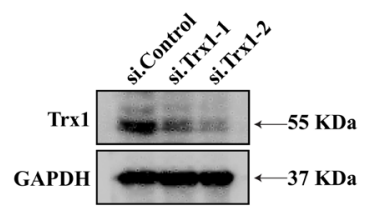

E

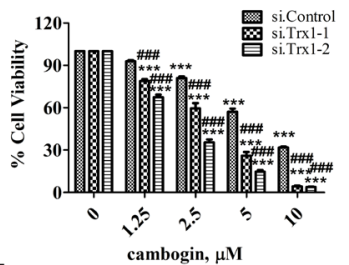

F

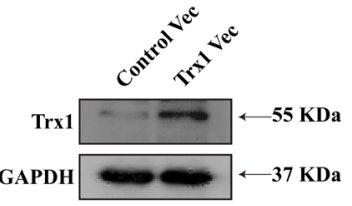

G

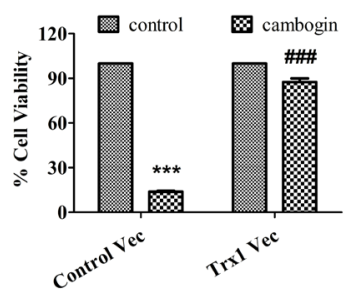

H

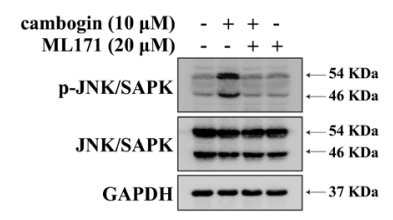

I
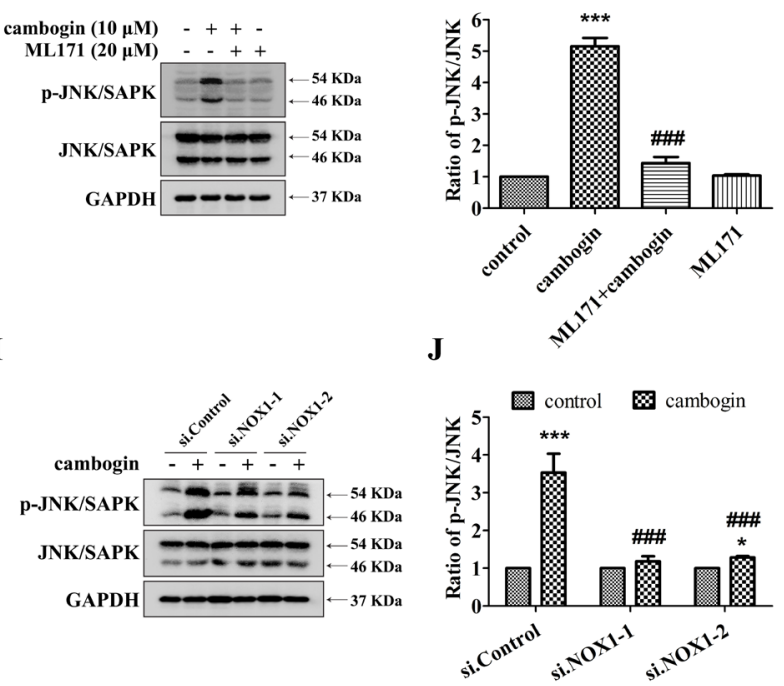

Figure 6: Cambogin leads to the dissociation of Trx1/ASK1 complexes and induces the phosphorylation of ASK1. A. Representative western blots for Trx1, phospho-ASK1, ASK1, phospho-JNK/SAPK, JNK/SAPK and GAPDH in MCF-7 cells stimulated with cambogin $(0-10 \mu \mathrm{M})$ for $24 \mathrm{~h}$. B. MCF-7 cells were incubated in the absence or presence of cambogin $(10 \mu \mathrm{M})$. Trx 1 was immunoprecipitated from cell lysates using anti-Trx1 antibodies. The immunoprecipitates were run on a SDS-PAGE gel, the upper half of the blot was probed with anti-ASK1 (top), and the bottom half with anti-Trx1. C. MCF-7 cells were transiently transfected with two independent Trx1 siRNA (si.Trx1-1 and si.Trx1-2) or control scrambled siRNA (si.Control) for $48 \mathrm{~h}$, levels of Trx 1 were determined by SDS-PAGE/Western blotting. GAPDH was served as a loading control. D. MCF-7 cells were transfected with si.Control, si.Trx1-1 or si.Trx1-2 for $24 \mathrm{~h}$, before treated with cambogin for another $24 \mathrm{~h}$. Cell viability was determined by MTT assay. E. MCF-7 cells were transiently transfected with Trx 1 (Trx1 Vec) or empty vector (Control Vec) for 48 h, levels of Trx 1 were determined by SDS-PAGE/Western blotting. GAPDH was served as a loading control. F. MCF-7 cells were transfected with Control Vec or Trx 1 Vec for 24 h, before treated with cambogin for another $24 \mathrm{~h}$. Cell viability was determined by MTT assay. G. MCF-7 cells were treated with cambogin for $24 \mathrm{~h}$ after pretreatment with ML171 $(20 \mu \mathrm{M})$ for $2 \mathrm{~h}$. The expression of phospho-JNK/SAPK and JNK/SAPK was determined by SDS-PAGE/Western blotting. H. The data are expressed as ratios to total JNK/SAPK. I. Representative blots for phospho-JNK/SAPK and JNK/SAPK in either control or NOX1-knocked down MCF-7 cells treated with vehicle control or cambogin $(10 \mu \mathrm{M})$ for 24 h. J. The data are expressed as ratios to total JNK/SAPK. Data are shown as means \pm SEM; ${ }^{* * *} P<0.001$ compared with control; ${ }^{\# \#} P<0.001$ compared with cambogin. $n=3$. 
can be inherently more resistant to oxidative stress than normal cells, and therefore oxidative stress may provide a selective advantage in tumor growth [31]. High ROS production also contributes to the cytotoxicity in response to anticancer drugs such as paclitaxel [28]. Indeed, we have previously demonstrated that the pro-apoptotic effect of cambogin in breast cancer cells is driven by high levels of ROS [21]. However, previous to this study, it was not known how ROS production is elevated in response to cambogin, and, in particular, how ROS production affects the apoptosis-dependent downstream signaling pathways in breast cancer cells.

Conventionally, intracellular ROS are mainly derived from the mitochondria and they are generated via electron leakage from mitochondrial electron transport, resulting in the regulation of oncogenic pathways [32]. Here we have shown that cambogin treatment increases mROS (mitochondrial ROS) accumulation in breast cancer cells. On the other hand, plasma membraneassociated NOX is the main source of the extracellular release of $\mathrm{O}_{2}{ }^{-}$. The activation of NOX is induced by the assembly of an active enzyme complex comprised of the catalytic subunits gp91 ${ }^{\text {phox }}, \mathrm{p} 22^{\text {phox }}$ and other components [13-17]. Cambogin is able to enhance membrane-bound $\mathrm{NOX}$ activity, leading to increased $\mathrm{O}_{2}$-- production, which is subsequently converted to $\mathrm{H}_{2} \mathrm{O}_{2}$. The inhibition of $\mathrm{NOX}$ by specific inhibitor apocynin or knocking down NOX using siRNA suppresses cambogin-induced elevation of ROS. Emerging evidence indicates that the production of ROS generated by the NOX enzymes is essential for oncogenesis and tumor progression [33]. Among the NOX family members, NOX1, in particular, has been responsible for elevated ROS levels in $80 \%$ of all human breast cancers [34]. The present data show that the generation of ROS is responsible for cambogin-induced interaction of $\mathrm{p} 22^{\text {phox }}$ and NOX1 in breast cancer cell membranes both in vitro and in vivo. This is evidenced by the fact that both NOX1 inhibitor ML171 or siRNA against NOX1 are able to prevent the elevation of $\mathrm{O}_{2}{ }^{-}$and $\mathrm{H}_{2} \mathrm{O}_{2}$ formation in response to cambogin.

Antioxidant enzymes, such as SOD, are ubiquitously expressed inside the cytoplasm $\left(\mathrm{Cu}^{2+} / \mathrm{Zn}^{2+} \mathrm{SOD}\right)$, mitochondria $\left(\mathrm{Mn}^{2+} \mathrm{SOD}\right)$ or outside $\left(\mathrm{Cu}^{2+} / \mathrm{Zn}^{2+} \mathrm{SOD}\right)$ the cell (also known as EC-SOD) [35]. Although ECSOD is mainly found in the extracellular matrix across all tissues, intracellular EC-SOD can also be detected [36]. The uptake of these antioxidative enzymes is not very well studied, but they did effectively prevent the inhibitory effect of cambogin on breast cancer cell proliferation. Therefore, all our data combined indicate that breast cancer progression can be effectively prevented by targeting the ROS/NOX1-dependent signaling transduction pathway, potentially providing several therapeutic targets for breast cancer treatment.

Cancer cells mainly rely on mitochondrial metabolism as their energy source due to their particular growth characteristics, implying that targeting mitochondria may constitute a relevant strategy for inhibiting tumor cell proliferation or inducing tumor cell apoptosis, especially in breast cancer [37]. Considering the fact that cambogin, a potent ROS-inducer, is able to selectively induce mitochondria abnormalities and apoptosis in breast cancer cells rather than normal cells; it is possible that the induction of changes in mitochondrial metabolism contributes to the pro-apoptotic effect of cambogin in breast cancer cells. An interesting and important concept is "mitochondrial criticality" which in some situations determines the life or death of a cell [38], it includes oscillations in mitochondrial energetics, inducing a state in which the mitochondrial network of cancer cells becomes very sensitive to small perturbations in ROS, resulting in the loss of $\Delta \Psi_{m}$ to the whole cells [39]. Indeed, cambogin induced both mROS accumulation and $\Delta \Psi_{m}$ dissipation in breast cancer cells. Emerging evidence indicates that mitochondrial clustering precedes cytochrome c release and an increase in the ratio of Bax/ Bcl-2 during etoposide-, paclitaxel- or curcumin-induced apoptosis in breast cancer cells [40-42]. It is likely that clustering of punctate mitochondria results from mitochondrial swelling, a consequence of mitochondrial dysfunction and integrity collapse. In view of previous studies [21] and present findings, the heavy fragmentation of mitochondria into punctuation and their clustering was specifically associated with cell damage as well as nuclear fragmentation and chromatin condensation, representing as hallmarks of breast cancer cell apoptosis in response to cambogin. A previous study from Lee et al. has shown that mROS is an essential trigger but not enough to promote cell death, which requires the sustained accumulation of ROS upon the subsequent activation of NOX1 [43]. Our findings indicated that the blockage of NOX1 activity attenuated the elevation of ROS production and mitochondrial network abnormalities induced by cambogin, further supporting the notion that NOX1 contributed to cambogin-induced mitochondrial disorders, which ultimately leading to apoptosis. These observations highlight the fact that mitochondria are important constituents of the positive feedback loops leading to mROS-triggered ROS production with subsequent mitochondria dysfunctions. Indeed, mitochondria and NOX1 also play a pivotal role in the progression of the pro-apoptotic effect in many other types of cancer $[33,34$, 38 ]; it can be tempting to speculate that targeting tumorspecific mitochondrial network abnormalities can be further exploited in the future to enhance the induction of tumor-targeting apoptosis.

ASK1, a ubiquitously expressed MAP kinase kinase kinase 5 (MAP3K5), is the central mediator of a prominent pathway that leads to cell apoptosis. When being active, ASK1 exists as a signalosome which can be found binding to another ASK1 molecule (homo-oligomerization). In contrast, in its inactive state, ASK1 is associated with 
negative regulators such as Trx1 [44], phosphatase 2C epsilon [45] and 14-3-3 [46]. For instance, Trx1 binds to the $N$ terminal non catalytic region of ASK1 under inhibitory conditions, upon ROS stimulation, residues Cys32 and Cys35 within Trx1 are oxidized and form an intramolecular disulfide, which leads to the subsequent dissociation of Trx1 from ASK1, facilitating ASK1 activation $[47,48]$. Activation of ASK1 in turn results in the phosphorylation of its downstream substrates such as p38 and JNK/SAPK, both of which have been reported to be implicated in the propagation of cell apoptosis [49]. Our previous study [21], together with the data presented here, indicate that cambogin treatment induces the activation of ASK1/JNK, but not that of p38 MAPK, in a time- and concentration-dependent manner. Supporting this view, co-immunoprecipitation studies using anti-Trx1/ ASK1 antibodies have also demonstrated that cambogin treatment significantly disturbed the binding between Trx 1 and ASK1. Trx1 is essential for cell survival in vitro [50], and Trx 2 knockout mice exhibit early embryonic lethality [51]. Inhibition of or knocking down Trx1 promotes oxidative stress as well as increases the sensitivity of cells to oxidants and redox-mediated apoptosis [52, 53]. Conversely, cells that overexpress Trx1 are more resistant to oxidant-induced apoptosis $[52,53]$. The interaction between Trx 1 and ASK1 is highly dependent on the redox status of Trx 1 and the oxidative state of Trx is unable to bind ASK1. The present findings provide direct evidence that Trx1 can be oxidized during cambogin treatment. Notably, we observed a reduction in Trx 1 protein levels upon cambogin treatment. Although oxidative stressinduced Trx1 degradation has already been reported elsewhere [54, 55], the underlying mechanism remains obscure, thereby how cambogin induces the reduction in Trx1 expression also awaits further study. Of note, the pro-apoptotic effect of cambogin was further aggravated when the cells were transiently transfected with siRNA against Trx1, suggesting that Trx1 inhibitors may enhance the effectiveness of cambogin in breast cancer treatment. Under the experimental conditions presented in this study, ROS is more likely to act as inducers of cancer cell apoptosis.

Although ASK1 can be activated by a number of stress stimuli including ROS in multiple cell types, its role as a downstream target of the NOX enzymes is still obscure. Before this report, we can only find out one study in the literature suggesting an interaction between ASK1 activation and NOX1 in vascular disease [56]. Our findings support the notion that there is a direct link between NOX1 and ASK1 which plays an important role in mediating breast cancer cell viability. We also demonstrated that the activation of ASK1 lies downstream of NOX1-derived ROS production in cambogin-treated breast cancer cells. Notably, the inhibition of NOX1 was sufficient to prevent the dissociation of Trx1 from ASK1 and hence the activation of ASK $1 / \mathrm{JNK}$, implying that targeting this pathway is likely to be a promising strategy for the treatment of breast cancer.

In conclusion, our findings indicate that in breast cancer cells, in response to cambogin treatment, the NOX enzyme is activated through the enhancement of $\mathrm{p} 22^{\text {phox }}$ and NOX1 interaction, and ROS derived from NOX stimulation subsequently leads to the dissociation of Trx1 from ASK1, resulting in the activation of ASK $1 /$ JNK pathway and the induction of mitochondrial network abnormalities, leading to the inhibition of breast adenocarcinoma cell proliferation and ultimately cell death. This work has a great impact on our understanding of the importance of ROS signaling pathway in breast cancer cell survival, and hence has provided more promising future therapeutic targets in the ongoing battle against breast cancer.

\section{MATERIALS AND METHODS}

\section{Chemical compound}

Cambogin was isolated from the branches of Garcinia esculenta. Its structure was determined using ${ }^{1} \mathrm{H}-\mathrm{NMR}$ and ${ }^{13} \mathrm{C}-\mathrm{NMR}$ spectral analysis, the achieved purity was more than $98 \%$ as determined by high performance liquid chromatography analysis. Cambogin was dissolved in absolute dimethyl sulfoxide (DMSO), and, on the experiment day, was further diluted with culture medium.

\section{Cell culture and transfection}

The human breast cancer cell lines (MCF-7, SKBR-3 and MDA-MB-468) were purchased in 2013 from the Chinese Academy of Science Committee Type Culture Collection Cell Bank (Shanghai, China). MCF-7 cells were cultured in Dulbecco's Modified Eagle Medium (DMEM, Invitrogen) with 10\% (v/v) fetal bovine serum (FBS, Invitrogen), $0.01 \mathrm{mg} / \mathrm{ml}$ bovine insulin (Sigma) and $1 \%$ penicillin/streptomycin (Invitrogen) at $37^{\circ} \mathrm{C}$ in a humidified atmosphere with $5 \% \mathrm{CO}_{2}$. SK-BR-3 cells were cultured in Dulbecco's Modified Eagle Medium (DMEM, Invitrogen) with 10\% (v/v) fetal bovine serum (FBS, Invitrogen) and $1 \%$ penicillin/streptomycin (Invitrogen) at $37^{\circ} \mathrm{C}$ in a humidified atmosphere with 5\% $\mathrm{CO}_{2}$. MDA-MB-468 cells were cultured in L15 medium (Invitrogen) with $10 \%(\mathrm{v} / \mathrm{v}) \mathrm{FBS}$ and $1 \%$ penicillin/ streptomycin at $37^{\circ} \mathrm{C}$ in a humidified atmosphere with $0 \% \mathrm{CO}_{2}$. Authenticity of these cell lines was performed using the standard short tandem repeat (STR) DNA typing methodology, by the Chinese Academy of Science Committee Type Culture Collection Cell Bank before purchase. No authentication of these cell lines was done by the authors. Cells were expanded and frozen in multiple vials after the $3^{\text {rd }}$ generation and passaged in culture for no more than 4 months after being thawed from the stocks. 
Culture medium was replaced every 2-3 days. Confluent cells were split at 1:3 ratios for maintenance. Cells were routinely tested for mycoplasma contamination.

In gene silencing experiments, MCF-7 cells were transfected with either a scramble siRNA or siRNAs against NOX1 or Trx1 using the lipofectamine RNA/ MAX kit (Invitrogen) according to the manufacturer's instructions. siRNAs against Trx 1-1: 5'-CCA CCA UUA AUG AAU UAG UTT-3' (sense) and 5'-ACU AAU UCA UUA AUG GUG GTT-3'(antisense); Trx1-2: 5'CUG CAG GUG AUA AAC UUG UTT-3' (sense) and 5'-ACA AGU UUA UCA CCU GCA GTT-3' (antisense); NOX1-1: 5'-GCC GAC AAA UAC UAC UAC ATT-3' (sense) and 5'-UGU AGU AGU AUU UGU CGG CTT3' (antisense); NOX1-2: 5'-GAU CCU AGA AAG GUU CAA UTT-3' (sense) and 5'-AUU GAA CCU UUC UAG GAU CTT-3' (antisense); scramble control, 5'-UUC UCC GAA CGU GUC ACG UTT-3' (sense) and 5'-ACG UGA CAC GUU CGG AGA ATT-3' (antisense). Plasmid transfection was performed using X-tremeGENE HP DNA Transfection (Roche, Penzberg, Germany) according to the manufacturer's protocol.

\section{Cell viability assay}

Where indicated, cells were pretreated with 1000 $\mathrm{U} / \mathrm{ml}$ catalase (CAT, Sigma), $100 \mathrm{U} / \mathrm{ml}$ superoxide dismutase (SOD, Sigma), $50 \mu \mathrm{M}$ EUK-8 (Sigma), 500 $\mu \mathrm{M}$ apocynin (Sigma) and/or $20 \mu \mathrm{M}$ ML171 (Tocris) for 2 $\mathrm{h}$, or transfected with NOX1 (20 nM) or Trx1 siRNA (20 $\mathrm{nM}$ ) for $24 \mathrm{~h}$, followed by the treatment with cambogin $(10 \mu \mathrm{M})$ for $24 \mathrm{~h}$. After treatment, 3-(4, 5-dimethylthiazol2-yl) 2, 5-diphenyltetrazolium bromide (MTT, Sigma) solution was added to the cells and the mixture was further incubated for $4 \mathrm{~h}$ at $37^{\circ} \mathrm{C}$. After removing the medium 100 $\mu \mathrm{l}$ DMSO was added and the absorbance was measured at $570 \mathrm{~nm}$, results were normalized as the percentage of control as readout of cell viability.

\section{Mitochondrial transmembrane potential $\left(\Delta \Psi_{\mathrm{m}}\right)$ assessment}

The electrical potential difference across inner mitochondrial membrane $\left(\Delta \Psi_{\mathrm{m}}\right)$ was monitored using the $\Delta \Psi_{\mathrm{m}}$ specific fluorescent probe JC-1 (Santa Cruz), a sensitive fluorescent dye. The JC-1 dye changes color as the membrane potential increases. At higher membrane potentials, JC-1 forms aggregates, resulting in changes of the fluorescence emission color from green to red. After treatment, cells were incubated with JC-1 (10 $\mu \mathrm{M})$ for $20 \mathrm{~min}$ at $37^{\circ} \mathrm{C}$ (protected from light). After incubation, stained cells were observed under a fluorescent microscope and then were assessed by microplate fluorescence reader. All experiments were carried out three times independently and five images per sample were selected randomly and blindly.

\section{Mitochondrial network imaging acquisition and length measurements}

The mitochondrial network was analyzed by staining with the mitochondria-targeting dye MitoTracker Red CMXRos (Invitrogen) as previously described [57] with minor modifications. Briefly, the cells were washed with Hank's balanced salt solution (HBSS), and stained with MitoTracker Red CMXRos (20 nM) in HBSS for $1 \mathrm{~h}$ at $37^{\circ} \mathrm{C}$ (protected from light). For confocal images, samples were obtained and acquired using Leica TCS SP8 equipped with digital inverted microscope at $\times 1000$ magnification. Images were enlarged and analyzed for mitochondrial length using LAS.F 3.3 software in a blind manner. Five images per sample were taken randomly and blindly for three independent experiments.

\section{Measurement of ROS}

After treatment, cells were stained with dihydroethidium (DHE, Sigma), 2', 7'-dichlorodihydrofluorescein diacetate (DCFH-DA, Sigma), or MitoSOX ${ }^{\mathrm{TM}}$ (Invitrogen), to detect $\mathrm{O}_{2}$. production, $\mathrm{H}_{2} \mathrm{O}_{2}$ production, or mitochondria $\mathrm{O}_{2}$. production, respectively. After incubation for $30 \mathrm{~min}$ at $37^{\circ} \mathrm{C}$ (in the absence of light), stained cells were observed under a fluorescent microscope (Olympus, Japan) and assessed by microplate fluorescence reader.

\section{Immunoprecipitation}

After treatment, cells were lysed in $0.3 \%(\mathrm{w} / \mathrm{v})$ CHAPS buffer (1 M HEPES pH7.5, $120 \mathrm{mM} \mathrm{NaCl}$, $1 \mathrm{mM}$ EDTA pH8, $10 \mathrm{mM}$ sodium pyrophosphate, 10 $\mathrm{mM} \beta$-glycerolphosphate, $50 \mathrm{mM} \mathrm{NaF}, 0.5 \mathrm{mM}$ sodium orthovanadate, $0.3 \%$ CHAPS, $1 \mathrm{mM}$ benzamidine- $\mathrm{HCl}$, $0.2 \mathrm{mM}$ phenylmethylsulfonyl fluoride, $1 \mu \mathrm{g} / \mathrm{ml}$ each of leupeptin and pepstatin). Protein lysates were spun for $10 \mathrm{~min}$ at $16,000 \mathrm{~g}$. The supernatants were kept, and total protein concentrations were determined using the Bradford assay. Lysates containing $1.2 \mathrm{mg}$ of total protein were incubated with anti-Trx1 antibody or anti-p22 $2^{\text {phox }}$ antibody for $16 \mathrm{~h}$ at $4^{\circ} \mathrm{C}$ with rotation, followed by the incubation with protein $\mathrm{A} / \mathrm{G}$ PLUS agarose beads for a further period of $2 \mathrm{~h}$ at $4^{\circ} \mathrm{C}$ with rotation. Beads were washed three times with $0.3 \%$ (w/v) CHAPS buffer, and the immunocomplexes were released by heating in a $2 \times$ Laemmli sample buffer and analysed by western blotting.

\section{SDS-PAGE and Western blotting}

After treatment, cells were lysed in RIPA buffer (Cat. \#: 9806, Cell Signaling Technology) containing 1 $\mathrm{mM}$ PMSF and protease inhibitor cocktail. Lysates were spun at $10,000 \mathrm{~g}$ for $10 \mathrm{~min}$ and the supernatants were kept at $-20^{\circ} \mathrm{C}$ until use. SDS-PAGE and Western blotting were 
Table 1: List of primary antibodies used in this study

\begin{tabular}{lllll}
\hline Primary antibody & Obtained from & Cat. No. & WB/IHC Dilution & Application \\
\hline p-p47phox S304 & Bioworld & BS4600 & $1: 500$ & WB \\
p22 ${ }^{\text {phox }}$ & SCB & sc-130551 & $1: 200 / 1: 50$ & WB/IF \\
NOX1 & abcam & ab55831 & $1: 1000 / 1: 500$ & WB/IF \\
Trx1 & SCB & sc-13526 & $1: 200 / 1: 10$ & WB/IP \\
p-JNK/SAPK Thr183 and Tyr185 & CST & 4668 & $1: 1000$ & WB \\
JNK/SAPK & CST & 9258 & $1: 1000$ & WB \\
p-ASK1 Thr845 & SCB & sc-109911 & $1: 200$ & WB \\
ASK1 & CST & 8662 & $1: 1000$ & WB \\
GAPDH & CST & 2118 & $1: 1000$ & WB \\
caveolin-1 & CST & 3238 & $1: 1000$ & WB \\
\hline
\end{tabular}

Dilution ratios given in the third lane are for WB, IF or IP. Abbreviations: CST: Cell Signalling Technology, USA; SCB: Santa Cruz Biotechnology, USA; Bioworld: Bioworld Technology, USA; WB: western blotting; IF: immunofluorescence; IP: Immunoprecipitation.

performed as previously described [21]. Please see Table 1 for a complete list of antibodies used in this study.

\section{Immunofluorescence assay}

After treatment, cells were fixed with $4 \%$ paraformaldehyde (PFA) for $30 \mathrm{~min}$ at room temperature. Fixed cells were blocked with $10 \%$ BSA in PBS for $1 \mathrm{~h}$. The cells or tumor tissue sections $(4 \mu \mathrm{m})$ were incubated with the primary antibodies against NOX1 and $\mathrm{p} 22^{\mathrm{phox}}$ overnight at $4^{\circ} \mathrm{C}$ followed by Alexa-Fluor 488-conjugated goat anti-rabbit IgG antibody and AlexaFluor 594-conjugated donkey anti-mouse IgG antibody for $2 \mathrm{~h}$ at room temperature. 4'6-diamidino-2-phenylindole (DAPI, Invitrogen) staining was then used to stain nuclei. For confocal images, samples were obtained randomly and acquired using Leica TCS SP8 equipped with digital inverted microscope at $\times 630$ magnification. Images were enlarged and analysed for PCC using LAS.F 3.3 software in a blind manner.

\section{NOX activity assay}

Cambogin treated MCF-7 cells were harvested and NOX activity was determined as previously described with minor modifications [58]. Briefly, cells were harvested and lysed in lysis buffer $(20 \mathrm{mM}$ potassium phosphate, pH7.0, $1 \mathrm{mM}$ EDTA, $10 \mu \mathrm{g} / \mathrm{ml}$ aprotinin, 0.5 $\mu \mathrm{g} / \mathrm{ml}$ leupeptin, $0.7 \mu \mathrm{g} / \mathrm{ml}$ pepstatin, and $0.5 \mathrm{mM}$ PMSF) after treatment. Protein lysates were spun for $20 \mathrm{~min}$ at $20,000 \mathrm{~g}$. The precipitates were washed with lysis buffer and then dissolved in $200 \mu$ loxidase assay buffer $(50 \mathrm{mM}$ potassium phosphate buffer, $\mathrm{pH}$ 7.0, 1 mM EDTA, 150 $\mathrm{mM}$ sucrose, $10 \mu \mathrm{g} / \mathrm{ml}$ aprotinin, $0.5 \mu \mathrm{g} / \mathrm{ml}$ leupeptin,
$0.7 \mu \mathrm{g} / \mathrm{ml}$ pepstain, and $0.5 \mathrm{mM}$ PMSF). Membrane samples $(50 \mu \mathrm{g}$ of total protein) were incubated with 5 $\mu \mathrm{M}$ lucigenin, $100 \mu \mathrm{M} \mathrm{NADPH}$, and NOX activity was measured immediately by measuring the luminescence produced by each sample at $37^{\circ} \mathrm{C}$. The emission of luminescence was recorded during $30 \mathrm{~s}$ intervals for 3 min. Results were blanked against background levels of luminescence. NOX activity is presented as the average luminescent counts per min (CPMs) per mg of protein.

\section{In vivo animal study}

BALB/c female nude mice ( 7 weeks old) were purchased from the Experimental Animal Center of Chinese Academy of Science (Shanghai, China). The experimental procedures were approved by the Shanghai University of Traditional Chinese Medicine Committee on the Use of Live Animals for Teaching and Research, and were carried out in accordance with the Guide for the Care and Use of Laboratory Animals, published by the National Institutes of Health (publication No. SCXX(HU) 20070005). MCF-7 breast cancer xenografts were performed as described [59]. Nude mice ( $\mathrm{n}=6$ each group) were given subcutaneous injections of MCF-7 cells $\left(3 \times 10^{6}\right.$ cells per mouse) into the mammary fat site. Before inoculation, $17 \beta$-estradiol (E2) pellets $(1.7 \mathrm{mg}$, 60-day release, produce 0.3-0.4 nmol/L E2 (blood levels); Innovative Research of America, Sarasota, FL) were implanted subcutaneously followed by the sealing of the incision with tissue adhesive Vetbond. After tumors had established $\left(\sim 50 \mathrm{~mm}^{3}\right)$, nude mice were divided randomly into two groups. Solvent control $(0.5 \%$ DMSO and $0.5 \%$ Tween- 80 in normal saline) and cambogin $(10 \mathrm{mg} / \mathrm{kg}$ in solvent control) were given via intraperitoneal injections every other 
day. After transplantation, the body weight and tumor sizes of all mice were recorded every three days. Tumor size was determined by Vernier caliper measurements and calculated as [(length $\times$ width $\left.\left.^{2}\right) / 2\right]$. After 35 days of treatment, mice were sacrificed and their tumors were removed, weighed, photographed, and fixed in 4\% PFA for immunofluorescence assay.

\section{SYBR Green assay}

Where indicated, cells were pretreated with $1000 \mathrm{U} /$ $\mathrm{ml} \mathrm{CAT,} 100 \mathrm{U} / \mathrm{ml}$ SOD, $50 \mu \mathrm{M}$ EUK-8, $500 \mu \mathrm{M}$ apocynin and/or $20 \mu \mathrm{M}$ ML171for $2 \mathrm{~h}$, or transfected with NOX1 $(20 \mathrm{nM})$ or Trx 1 siRNA $(20 \mathrm{nM})$ for $24 \mathrm{~h}$, followed by the treatment with cambogin $(10 \mu \mathrm{M})$ for $24 \mathrm{~h}$. After medium was removed, $100 \mu \mathrm{l}$ of SYBR Green $(1: 10000)$ in lysis buffer were added and the fluorescence intensity units (FIU) were measured at $485 \mathrm{~nm}$ (excitation wavelength) and $530 \mathrm{~nm}$ (emission wavelength).

\section{Measurement of NO production}

NO production was measured by using a NO assay kit (Cat. \#: S0023, Beyotime Institute of Bitotechnology) as previously described with minor modifications [60]. Briefly, cambogin treated MCF-7 cells were harvested and lysed in lysis buffer for NO assay (\#S3090, Beyotime Institute of Bitotechnology). The production of $\mathrm{NO}$ was determined by measuring the levels of nitrite according to the Griess method. The absorbance was measured at $540 \mathrm{~nm}$, and the production of NO from the samples was calculated using increasing concentrations of sodium nitrite as a reference standard curve.

\section{Measurement of $\mathrm{H}_{2} \mathrm{O}_{2}$ production}

The production of $\mathrm{H} 2 \mathrm{O} 2$ was measured by using a $\mathrm{H}_{2} \mathrm{O}_{2}$ assay kit (Cat. \#: S0038, Beyotime Institute of Bitotechnology) as previously described with minor modifications [61]. Briefly, cambogin treated MCF-7 cells were harvested and lysed in lysis buffer supplied by the kit. The absorbance was measured at $560 \mathrm{~nm}$. Concentrations of hydrogen peroxide from the samples were calculated by interpolation from the standard curves established using reagents provided by the kit.

\section{Statistical analysis}

Data are presented as means \pm SEM. Statistical analysis was performed using one- or two-way ANOVA for multiple comparisons or Student's unpaired $t$-test for single comparisons. $P$ values less than 0.05 were considered to indicate statistically significant differences.

\section{CONFLICTS OF INTEREST}

No potential conflicts of interest were disclosed.

\section{GRANT SUPPORT}

This work was supported financially by the Foundation of Shanghai University of Traditional Chinese Medicine (2012JW05 to K. Shen), National Natural Science Foundation of China (81303266 to K. Shen; 81303188 to H. Zhang), Natural Science and Technology Foundation for Distinguished Young Scholars of Shanghai (13ZR1462000 to K. Shen), Chen Guang Foundation of Shanghai Ministry of Education (13CG46 to K. Shen), and 085 special project for the Priority Academic Program Development of Shanghai Higher Education Institutions (ZYX-CXYJ-012 to H.Xu).

\section{REFERENCES}

1. DeSantis C, Ma J, Bryan L, Jemal A. Breast cancer statistics 2013. CA Cancer J Clin. 2014; 64: 52-62.

2. Surakasula A, Nagarjunapu GC, Raghavaiah KV. A comparative study of pre- and post-menopausal breast cancer: Risk factors, presentation, characteristics and management. J Res Pharm Pract. 2014; 3: 12-18.

3. Liochev SI, Fridovich I. Superoxide and iron: partners in crime. IUBMB Life. 1999; 48: 157-161.

4. Sart S, Song L, Li Y. Controlling Redox Status for Stem Cell Survival, Expansion, and Differentiation. Oxid Med Cell Longev. 2015; 2015: 105135.

5. Tochhawng L, Deng S, Pervaiz S, Yap CT. Redox regulation of cancer cell migration and invasion. Mitochondrion. 2013; 13: 246-253.

6. Garrido-Urbani S, Jaquet V, Imhof BA. ROS and NADPH oxidase: key regulators of tumor vascularization. Med Sci (Paris). 2014; 30: 415-421.

7. Bossis G, Sarry JE, Kifagi C, Ristic M, Saland E, Vergez F, Salem T, Boutzen H, Baik H, Brockly F, Pelegrin M, Kaoma T, Vallar L, et al. The ROS/SUMO axis contributes to the response of acute myeloid leukemia cells to chemotherapeutic drugs. Cell Rep. 2014; 7: 1815-1823.

8. Agostinis P, Berg K, Cengel KA, Foster TH, Girotti AW, Gollnick SO, Hahn SM, Hamblin MR, Juzeniene A, Kessel D, Korbelik M, Moan J, Mroz P, et al. Photodynamic therapy of cancer: an update. CA Cancer J Clin. 2011; 61: 250-281.

9. Azzam EI, Jay-Gerin JP, Pain D. Ionizing radiation-induced metabolic oxidative stress and prolonged cell injury. Cancer Lett. 2012; 327: 48-60.

10. Bedard K, Krause KH. The NOX family of ROS-generating NADPH oxidases: physiology and pathophysiology. Physiol Rev. 2007; 87: 245-313.

11. Fleury C, Mignotte B, Vayssiere JL. Mitochondrial reactive oxygen species in cell death signaling. Biochimie. 2002; 84: 131-141. 
12. Bokoch GM, Knaus UG. NADPH oxidases: not just for leukocytes anymore! Trends Biochem Sci. 2003; 28: 502-508.

13. Lambeth JD. NOX enzymes and the biology of reactive oxygen. Nat Rev Immuno. 2004; 4: 181-189.

14. Bedard K, Krause KH. The NOX family of ROS-generating NADPH oxidases: physiology and pathophysiology. Physiol Res. 2007; 87: 245-313.

15. Geiszt M, Leto TL. The Nox family of NAD $(\mathrm{P}) \mathrm{H}$ oxidase: host defense and beyond. J Biol Chem. 2004; 279: 51715-51718.

16. Cheng G, Diebold BA, Hughes Y, Lambeth JD. Nox1dependent reactive oxygen generation is regulated by Rac1. J Biol Chem. 2006; 281: 17718-17726.

17. Miyano K, Sumimoto H. Role of the small GTPase Rac in p22phox-dependent NADHP oxidases. Biochimie. 2007; 89: 1133-1144.

18. Han QB, Xu HX. Caged Garcinia xanthones: development since 1937. Curr Med Chem. 2009; 16: 3775-3796.

19. Kan WL, Yin C, Xu HX, Xu G, To KK, Cho CH, Rudd JA, Lin G. Antitumor effects of novel compound, guttiferone K, on colon cancer by $\mathrm{p} 21$ Waf1/Cip1-mediated $\mathrm{G}(0) / \mathrm{G}(1)$ cell cycle arrest and apoptosis. Int J Cancer. 2013; 132: 707-716.

20. Wang X, Lao Y, Xu N, Xi Z, Wu M, Wang H, Li X, Tan $\mathrm{H}$, Sun $\mathrm{M}, \mathrm{Xu} \mathrm{H}$. Oblongifolin $\mathrm{C}$ inhibits metastasis by up-regulating keratin 18 and tubulins. Sci Rep. 2015; 5: 10293.

21. Shen K, Xie J, Wang H, Zhang H, Yu M, Lu F, Tan H, Xu H. Cambogin induces caspase-independent apoptosis through the ROS/JNK pathway and epigenetic regulation in breast cancer cells. Mol Cancer Ther. 2015; 14: 1738-1749.

22. Cheng AC, Tsai ML, Liu CM, Lee MF, Nagabhushanam $\mathrm{K}$, Ho CT, Pan MH. Garcinol inhibits cell growth in hepatocellular carcinoma Hep3B cells through induction of ROS-dependent apoptosis. Food Funct. 2010; 1: 301-307.

23. Zhang H, Zhang DD, Lao YZ, Fu WW, Liang S, Yuan $\mathrm{QH}$, Yang L, Xu HX. Cytotoxic and anti-inflammatory prenylated benzoylphloroglucinols and xanthones from the twigs of Garcinia esculenta. J Nat Prod. 2014; 77: 1700-1707.

24. Sarosiek KA, Ni Chonghaile T, Letai A. Mitochondria: gatekeepers of response to chemotherapy. Trends Cell Biol. 2013; 23: 612-619.

25. Cory S, Huang DC, Adams JM. The Bcl-2 family: roles in cell survival and oncogenesis. Oncogene. 2003; 22: 8590-8607.

26. Kello M, Drutovic D, Chripkova M, Pilatova M, Budovska M, Kulikova L, Urdzik P, Mojzis J. ROSdependent antiproliferative effect of brassinin derivative homobrassinin in human colorectal cancer $\mathrm{Caco} 2$ cells. Molecules. 2014; 19: 10877-10897.

27. Jo GH, Kim GY, Kim WJ, Park KY, Choi YH. Sulforaphane induces apoptosis in T24 human urinary bladder cancer cells through a reactive oxygen species-mediated mitochondrial pathway: The involvement of endoplasmic reticulum stress and the Nrf2 signaling pathway. Int J Oncol. 2014; 45: 1497-1506.

28. Alexandre J, Hu Y, Lu W, Pelicano H, Huang P. Novel action of paclitaxel against cancer cells: bystander effect mediated by reactive oxygen species. Cancer Res. 2007; 67: 3512-3517.

29. Weaver JR, Grzesik W, Taylor-Fishwick DA. Inhibition of NADPH oxidase-1 preserves beta cell function. Diabetologia. 2015; 58: 113-121.

30. Lu J, Holmgren A. Thioredoxin system in cell death progression. Antioxid Redox Signal. 2012; 17: 1738-1747.

31. Ushio-Fukai M, Nakamura Y. Reactive oxygen species and angiogenesis: NADPH oxidase as target for cancer therapy. Cancer Lett. 2008; 266: 37-52.

32. Starkov AA. The role of mitochondria in reactive oxygen species metabolism and signaling. Ann N Y Acad Sci. 2008; 1147: 37-52.

33. Bonner MY, Arbiser JL. Targeting NADPH oxidases for the treatment of cancer and inflammation. Cell Mol Life Sci. 2012; 69: 2435-2442.

34. Desouki MM, Kulawiec M, Bansal S, Das GM, Singh KK. Cross talk between mitochondria and superoxide generating NADPH oxidase in breast and ovarian tumors. Cancer Biol Ther. 2005; 4: 1367-1373.

35. Marklund SL. Extracellular superoxide dismutase in human tissues and human cell lines. J Clin Invest. 1984; 74: 1398-1403.

36. Nozik-Grayck E, Suliman HB, Piantadosi CA. Extracellular superoxide dismutase. Int J Biochem Cell Biol. 2005; 37 : 2466-2471.

37. Mishra P, Ambs S. Metabolic signatures of human breast cancer. Mol Cell Oncol. 2015; 2: e992217.

38. Aon MA, Cortassa S, Akar FG, O'Rourke B. Mitochondrial criticality: a new concept at the turning point of life or death. Biochim Biophys Acta. 2006; 1762: 232-240.

39. Aon MA, Cortassa S, O'Rourke B. Percolation and critically in a mitochondrial network. Proc Natl Acad Sci U S A. 2004; 101: 4447-4452.

40. Thomadaki H, Talieri M, Scorilas A. Treatment of MCF-7 cells with taxol and etoposide induces distinct alterations in the expression of apoptosis-related genes BCL2, BCL2L12, BAX, CASPASE-9 and FAS. Biol Chem. 2006; 387: 1081-1086.

41. Haldar S, Basu A, Croce CM. Bcl2 is the guardian of microtubule integrity. Cancer Res. 1997; 57: 229-233.

42. Mohankumar K, Pajaniradje S, Sridharan S, Singh VK, Ronsard L, Banerjea AC, Benson CS, Coumar MS, Rajagopalan R. Mechanism of apoptotic induction in human breast cancer cell, MCF-7, by an analog of curcumin in comparison with curcumin-an in vitro and in silico approach. Chem Biol Interact. 2014; 210: 51-63.

43. Arteel GE, Briviba K, Sies H. Protection against peroxynitrite. FEBS Lett. 1999; 445: 226-230. 
44. Saitoh M, Nishitoh H, Fujii M, Takeda K, Tobiume K, Sawada Y, Kawabata M, Miyazono K, Ichijo H. Mammalian thioredoxin is a direct inhibitor of apoptosis signalregulating kinase (ASK) 1. EMBO J. 1998; 17: 2596-2606.

45. Saito J, Toriumi S, Awano K, Ichijo H, Sasaki K, Kobayashi $\mathrm{T}$, Tamura S. Regulation of apoptosis signal-regulating kinase 1 by protein phosphatase 2Cepsilon. Biochem J. 2007; 405: 591-596.

46. Goldman EH, Chen L, Fu H. Activation of apoptosis signalregulating kinase 1 by reactive oxygen species through dephosphorylation at serine 967 and 14-3-3 dissociation. J Biol Chem. 2004; 279: 10442-10449.

47. Liu H, Nishitoh H, Ichijo H, Kyriakis JM. Activation of apoptosis signal-regulating kinase 1 (ASK1) by tumor necrosis factor receptor-associated factor 2 requires prior dissociation of the ASK1 inhibitor thioredoxin. Mol Cell Biol. 2006; 20: 2198-2208.

48. Tobiume K, Saitoh M, Ichijo H. Activation of apoptosis signal-regulating kinase 1 by the stress-induced activating phosphorylation of pre-formed oligomer. J Cell Physiol. 2002; 191: 95-104.

49. Sumbayev VV, Yasinska IM. Regulation of MAP kinasedependent apoptotic pathway: implication of reactive oxygen and nitrogen species. Arch Biochem Biophys. 2005; 436: 406-412.

50. Powis G, Montfort WR. Properties and biological activities of thioredoxins. Annu Rev Biophys Biomol Struct. 2001; 30: 421-455.

51. Nonn L, Williams RR, Erickson RP, Powis G. The absence of mitochondrial thioredoxin 2 causes massive apoptosis, exencephaly, and early embryonic lethality in homozygous mice. Mol Cell Biol. 2003; 23: 916-922.

52. Hansen JM, Go YM, Jones DP. Nuclear and mitochondrial compartmentation of oxidation stress and redox signaling. Annu Rev Pharmacol Toxicol. 2006; 46: 215-234.

53. Chen Y, Cai J, Jones DP. Mitochondrial thioredoxin in regulation of oxidant-induced cell death. FEBS Lett. 2006; 580: 6596-6602.
54. Zhang X, Lu J, Ren X, Du Y, Zheng Y, Ioannou PV, Holmgren A. Oxidation of structural cysteine residues in thioredoxin 1 by aromatic arsenicals enhances cancer cell cytotoxicity caused by the inhibition of thioredoxin reductase 1. Free Radic Biol Med. 2015; 89: 192-200.

55. Zschauer TC, Kunze K, Jakob S, Haendeler J, Altschmied J. Oxidative stress-induced degradation of thioredoxin-1-actin interaction in endothelial cells. Arterioscler Thromb Vasc Biol. 2011; 31: 650-656.

56. Al Ghouleh I, Fazziano G, Rodriguez Al, Csanyi G, Maniar S, St Croix CM, Kelley EE, Egana LA, Song GJ, Bisello A, Lee YJ, Pagano PJ. Aquaporin 1, NOX 1, and Ask 1 mediate oxidant-induced smooth muscle cell hypertrophy. Cardiovasc Res. 2013; 97: 134-142.

57. Akita M, Suzuki-Karasaki M, Fujiwara K, Nakagawa C, Soma M, Yoshida Y, Ochiai T, Tokuhashi Y, SuzukiKarasaki. Mitochondrial division inhibitor-1 induces mitochondrial hyperfusion and sensitizes human cancer cells to TRAIL-induced apoptosis. Int J Oncol. 2014; 45: 1901-1912.

58. Hsieh CJ, Kuo PL, Hsu YC, Huang YF, Tsai EM, Hsu YL. Arctigenin, a dietary phytoestrogen, induces apoptosis of estrogen receptor-negative breast cancer cells through the ROS/p38 MAPK pathway and epigenetic regulation. Free Radic Biol Med. 2014; 67: 159-170.

59. Chen J, Hui E, Ip T, Thompson LU. Dietary flaxseed enhances the inhibitory effect of tamoxifen on the growth of estrogen-dependent human breast cancer (MCF-7) in nude mice. Clin Cancer Res. 2004; 10: 7703-7711.

60. Wang M, Zhao XR, Wang P, Li L, Dai Y, Huang H, Lei $\mathrm{P}$, Zhu HF, Shen GX. Glucose regulated proteins 78 protects insulinoma cells (NIT-1) from death induced by streptozotocin, cytokines or cytotoxic T lymphocytes. Int J Biochem Cell Biol. 2007; 39: 2076-2082.

61. Jiang S, Zu Y, Wang Z, Zhang Y, Fu Y. Involvement of mitochondrial permeability transition pore opening in 7-xylosyl-10-deacetylpaclitaxel-induced apoptosis. Planta Med. 2011; 77: 1005-1012. 